Prepared in cooperation with the Bureau of Reclamation, New Mexico Office of the State Engineer, City of Las Cruces Utilities, New Mexico Interstate Stream Commission, New Mexico State University, and the Elephant Butte Irrigation District

\title{
Seepage Investigation of the Rio Grande From Below Leasburg Dam, Leasburg, New Mexico, to Above El Paso, Texas, 2018
}

Scientific Investigations Report $2019-5140$ 
Cover. Photograph showing north-oriented view of the Rio Grande and the NM-128 bridge near Mesquite, New Mexico, April 4, 2018. Photograph by Grady Ball, U.S. Geological Survey. 


\section{Seepage Investigation of the Rio Grande From Below Leasburg Dam, Leasburg, New Mexico, to Above El Paso, Texas, 2018}

By Grady P. Ball, Andrew J. Robertson, and Karen Medina Morales

Prepared in cooperation with the Bureau of Reclamation, New Mexico Office of the State Engineer, City of Las Cruces Utilities, New Mexico Interstate Stream Commission, New Mexico State University, and the Elephant Butte Irrigation District

Scientific Investigations Report 2019-5140 


\title{
U.S. Department of the Interior DAVID BERNHARDT, Secretary
}

\author{
U.S. Geological Survey \\ James F. Reilly II, Director
}

U.S. Geological Survey, Reston, Virginia: 2020

For more information on the USGS - the Federal source for science about the Earth, its natural and living resources, natural hazards, and the environment-visit https://www.usgs.gov or call 1-888-ASK-USGS.

For an overview of USGS information products, including maps, imagery, and publications, visit https://store.usgs.gov.

Any use of trade, firm, or product names is for descriptive purposes only and does not imply endorsement by the U.S. Government.

Although this information product, for the most part, is in the public domain, it also may contain copyrighted materials as noted in the text. Permission to reproduce copyrighted items must be secured from the copyright owner.

Suggested citation:

Ball, G.P., Robertson, A.J., and Medina Morales, K., 2020, Seepage investigation of the Rio Grande from below Leasburg Dam, Leasburg, New Mexico, to above El Paso, Texas, 2018: U.S. Geological Survey Scientific Investigations Report 2019-5140, 16 p., https://doi.org/10.3133/sir20195140.

ISSN 2328-0328 (online) 


\section{Contents}

Abstract

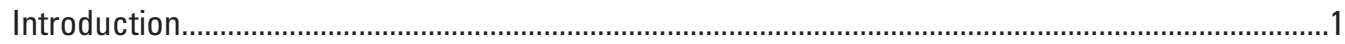

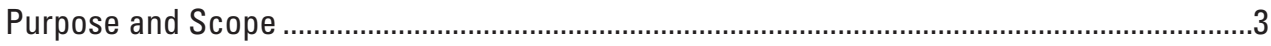

Description of Study Reach and Measurement Locations .....................................................

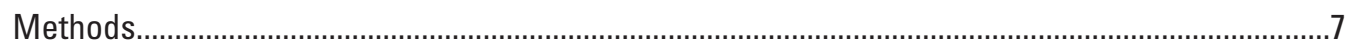

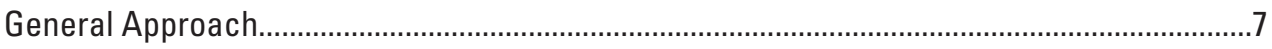

Measurement of Streamflow and Wastewater Treatment Plant Discharge ............................7

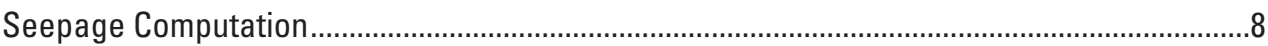

Net Seepage Gain or Loss..........................................................................................

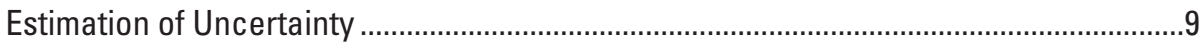

Determination of Meaningful Computed Seepage Gain or Loss ....................................10

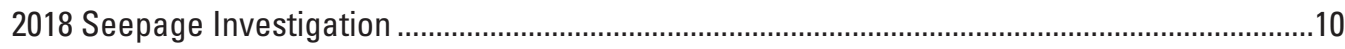

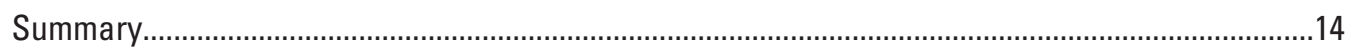

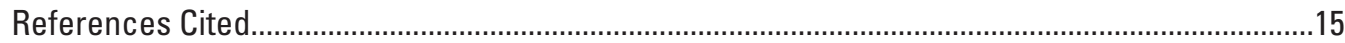

\section{Figures}

1. Map showing measurement locations for the U.S. Geological Survey Rio Grande seepage investigation from below Leasburg Dam, Leasburg, New Mexico, to above El Paso, Texas, 2018 .

2. Schematic showing measurement locations for U.S. Geological Survey Rio Grande seepage investigation from below Leasburg Dam, Leasburg, New Mexico, to above El Paso, Texas, 2018, and the locations of inflows to the river within the study reach

\section{Tables}

1. Locations of U.S. Geological Survey Rio Grande seepage investigation streamflow measurement sites from below Leasburg Dam, Leasburg, New Mexico, to above El Paso, Texas, April 3-4, 2018

2. Summary of measured streamflow and the computed net seepage gain or loss in streamflow in subreaches, Rio Grande seepage investigation, April 3-4, 2018.

3. Select field measurements and observations, Rio Grande seepage investigation, 2018

4. Summary of the cumulative gain or loss in streamflow due to seepage along subreaches within the study reach, Rio Grande seepage investigations, 2006-15 and 2018 


\section{Conversion Factors}

U.S. customary units to International System of Units

\begin{tabular}{|c|c|c|}
\hline Multiply & By & To obtain \\
\hline \multicolumn{3}{|c|}{ Length } \\
\hline inch (in.) & 2.54 & centimeter $(\mathrm{cm})$ \\
\hline inch (in.) & 25.4 & millimeter $(\mathrm{mm})$ \\
\hline mile (mi) & 1.609 & kilometer $(\mathrm{km})$ \\
\hline \multicolumn{3}{|c|}{ Flow rate } \\
\hline cubic foot per second $\left(\mathrm{ft}^{3} / \mathrm{s}\right)$ & 0.02832 & cubic meter per second $\left(\mathrm{m}^{3} / \mathrm{s}\right)$ \\
\hline
\end{tabular}

Temperature in degrees Celsius $\left({ }^{\circ} \mathrm{C}\right)$ may be converted to degrees Fahrenheit $\left({ }^{\circ} \mathrm{F}\right)$ as

$$
{ }^{\circ} \mathrm{F}=\left(1.8 \times{ }^{\circ} \mathrm{C}\right)+32 .
$$

Temperature in degrees Fahrenheit $\left({ }^{\circ} \mathrm{F}\right)$ may be converted to degrees Celsius $\left({ }^{\circ} \mathrm{C}\right)$ as

$$
{ }^{\circ} \mathrm{C}=\left({ }^{\circ} \mathrm{F}-32\right) / 1.8 \text {. }
$$

\section{Datum}

Horizontal coordinate information is referenced to the North American Datum of 1983 (NAD 83).

\section{Abbreviations}

ADCP acoustic Doppler current profiler

ADV acoustic Doppler velocimeter

EBID Elephant Butte Irrigation District

USGS U.S. Geological Survey

WWTP wastewater treatment plant 


\title{
Seepage Investigation of the Rio Grande From Below Leasburg Dam, Leasburg, New Mexico, to Above El Paso, Texas, 2018
}

\author{
By Grady P. Ball, ${ }^{1}$ Andrew J. Robertson, ${ }^{1}$ and Karen Medina Morales ${ }^{2}$
}

\section{Abstract}

Seepage investigations were conducted periodically by the U.S. Geological Survey (USGS) from 1988 to 1998 and from 2006 to 2015 along a 64-mile reach of the Rio Grande as part of the Mesilla Basin monitoring program. Past studies were conducted during no-flow or low-flow periods. In 2018, a seepage investigation was conducted during April 3-4 along a 62.4-mile study reach, from below Leasburg Dam, Leasburg, New Mexico, to above El Paso, Texas, during a period of high flows due to dam releases of water for irrigation purposes. During this investigation, there was measurable streamflow at 31 of the 41 measurement locations: 22 river sites, 8 inflow sites, and 1 outflow site. Results of the 2018 high-flow seepage investigation are presented in this report.

Net seepage gain or loss was computed for each subreach (the interval between two adjacent measurement locations along the river) by subtracting the streamflow measured at the upstream location from the streamflow measured at the closest downstream location and then subtracting any inflow to the river within the subreach. An estimated gain or loss was determined to be meaningful if it exceeded the cumulative measurement uncertainty associated with the net seepage computation. During this investigation, streamflow on the main stem of the Rio Grande ranged from 577 to 1,000 cubic feet per second $\left(\mathrm{ft}^{3} / \mathrm{s}\right)$. Nine subreaches were found to have meaningful net seepage gain or loss, four gaining subreaches and five losing subreaches. Because of high cumulative uncertainty (plus or minus $111.3 \mathrm{ft}^{3} / \mathrm{s}$ ) relative to the calculated cumulative loss $\left(-57.7 \mathrm{ft}^{3} / \mathrm{s}\right)$ over the entire study reach, no meaningful gain or loss was determined in this study. Like all of the previous USGS seepage studies on this reach of the Rio Grande, this study reported a net seepage loss, and the magnitude of that loss was within the range of historical values.

${ }^{1}$ U.S. Geological Survey.

${ }^{2}$ New Mexico State University.

\section{Introduction}

Increasing water demand and multiyear drought conditions (National Drought Mitigation Center, 2018) within the Mesilla Basin and adjacent areas (fig. 1) have resulted in diminished surface-water supplies and increased groundwater withdrawals in the basin. In 1987, the U.S. Geological Survey (USGS) established the Mesilla Basin monitoring program (https:// www.usgs.gov/centers/nm-water/science/monitoring-networkgroundwater-flow-system-and-stream-aquifer-relations?qtscience_center_objects $=0 \#$ qt-science_center_objects) to document and identify trends in groundwater conditions and relations between streams and aquifers. The monitoring program continues through the present (2019) in cooperation with a variety of entities at the Federal, State, and local levels with an interest in the Mesilla Basin.

Seepage investigations on the Rio Grande from below Leasburg Dam, Leasburg, New Mexico, to above American Dam, El Paso, Texas, have been a component of the Mesilla Basin monitoring program since 1988. Seepage investigations were conducted periodically by the USGS from 1988 to 1998 and from 2006 to 2015 along a 64-mile reach of the Rio Grande. These past studies were conducted during no-flow or low-flow periods. In 2018, a seepage investigation was conducted by the USGS in cooperation with the Bureau of Reclamation, New Mexico Office of the State Engineer, City of Las Cruces Utilities, New Mexico Interstate Stream Commission, New Mexico State University, and the Elephant Butte Irrigation District (EBID). The seepage investigation occurred on April 3 and 4 along a 62.4-mile study reach, from below Leasburg Dam, Leasburg, N. Mex., to above El Paso, Tex., during a period of high flows caused by dam releases of water for irrigation purposes. Seepage investigations are typically conducted during low-flow conditions. In 2018, high-flow conditions corresponded to an irrigation release intended to supply El Paso Irrigation District, downstream of the study reach, during a period when no other irrigation was occurring. This offered an opportunity to measure seepage gains and losses when there were limited diversions from and returns to the river within the study reach, such that measured changes would be indicative of seepage gains or losses. Results of the 2018 high-flow seepage investigation are presented in this report. 


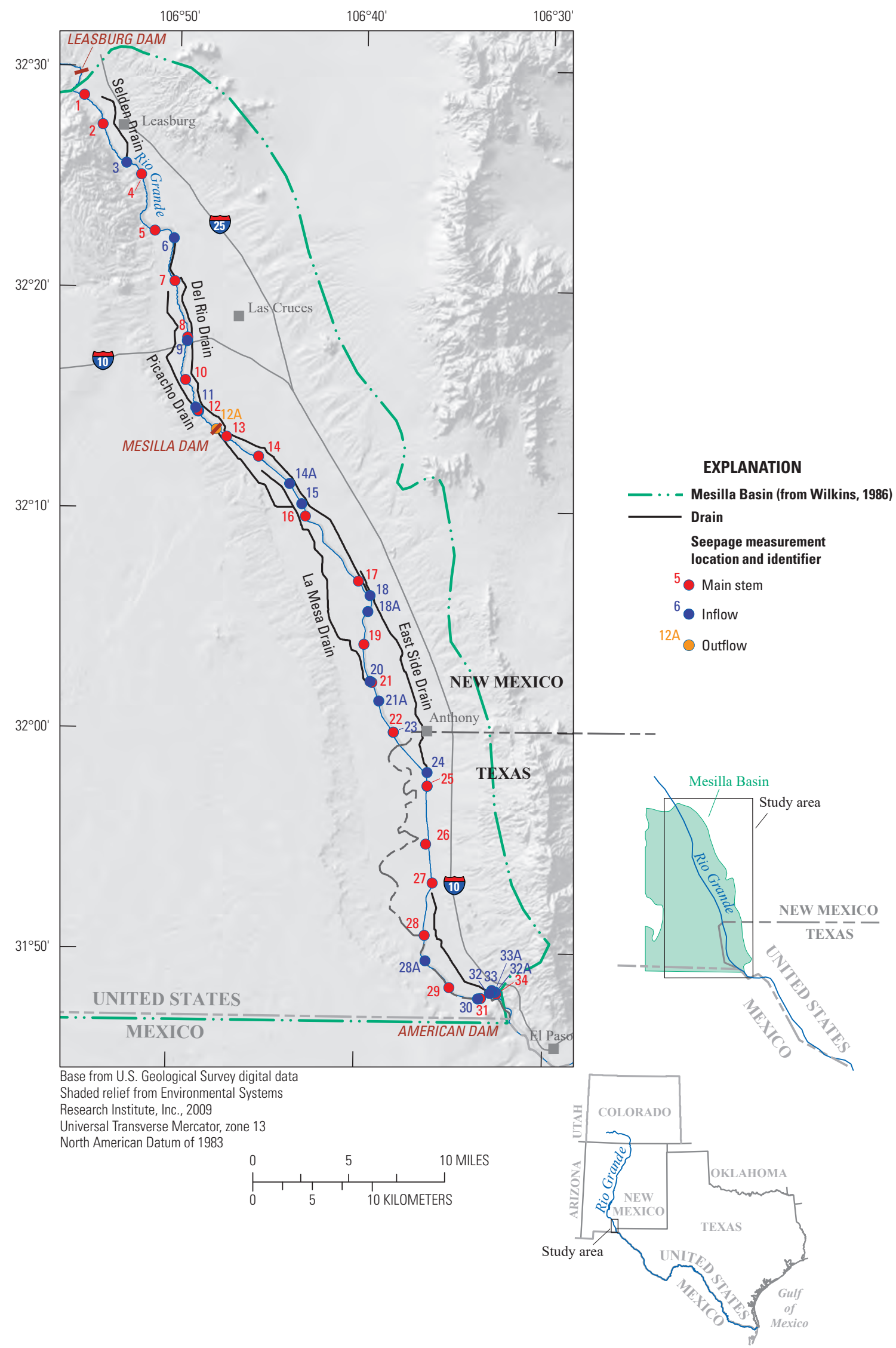

Figure 1. Measurement locations for the U.S. Geological Survey Rio Grande seepage investigation from below Leasburg Dam, Leasburg, New Mexico, to above El Paso, Texas, 2018. 
Streamflow in this reach of the Rio Grande is largely controlled by irrigation releases from Caballo Dam, located on the Rio Grande about 50 miles upstream from Leasburg, N. Mex. (Moyer and others, 2013). Seepage gain is the interstitial movement of water from the subsurface into a body of surface water, whereas seepage loss is the interstitial movement of water from a body of surface water into the subsurface (U.S. Geological Survey, 2013). Gains or losses in streamflow to the Rio Grande can result from seepage in the streambed or from changes in bank storage, evaporation from the water surface, and transpiration by vegetation along the river banks.

Information on seepage gains or losses in the Rio Grande is important to water managers in the Mesilla Basin, where water users rely on surface-water and groundwater supplies in a highly interconnected hydrogeologic basin (Moyer and others, 2013). Results of seepage investigations on the Rio Grande conducted annually by the USGS from 1988 to 1998 and from 2004 to 2005 were published in USGS annual water-data reports (Beal and Gold, 1989; Borland and others, 1990, 1991, 1992; Cruz and others, 1993, 1994; Ortiz and Lange, 1996, 1997; Ortiz and others, 1998, 1999; Byrd, 2005; Miller and Stiles, 2006). The results of seepage investigations from 2006 to 2013 were published in Crilley and others (2013). The 2014 and 2015 seepage investigations were published in Briody and others (2016a, 2016b). Study design and methods presented in this report for the 2018 seepage investigation follow those in Crilley and others (2013).

\section{Purpose and Scope}

This report describes the methods used to obtain streamflow measurements and to calculate seepage gain or loss and presents the results of the seepage investigation conducted along the Rio Grande from below Leasburg Dam, Leasburg, N. Mex., to above El Paso, Tex. (hereafter referred to as the "study reach"), during April 3-4, 2018. Streamflow measurements or wastewater treatment plant (WWTP) discharge measurements (collectively referred to as "streamflow measurements") for 22 river sites, 8 inflow sites, and 1 outflow site are presented for this seepage investigation. Net seepage gain or loss in the river, computed on the basis of streamflow measurements for 21 subreaches within the study reach, is presented. A subreach is defined as the interval between two adjacent main-stem measurement locations along the river. Inflow and outflow sites without flow, in this and previous investigations, were observed and recorded (USGS, 2018) but are not included in the tables or discussion. Data generated during this study are available from the USGS National Water Information System database (USGS, 2018).

\section{Description of Study Reach and Measurement Locations}

The 2018 study reach is a 62.4-mile section of the Rio Grande from USGS streamgage Rio Grande below Leasburg Dam, N. Mex. (station identification 322841106551010; site 1), to USGS streamgage Rio Grande at El Paso, Tex. (station identification 08364000; site 34) (fig. 1, table 1). Measurement sites followed those established in the previous seepage investigations (1988-98 and 2006-15) (figs. 1 and 2, table 1). Site numbering followed the nomenclature established during the 1988 seepage investigation with sites added as needed. The most southerly site used in the previous studies, Rio Grande above American Dam at El Paso, Tex. (08364000), was excluded from the 2018 seepage investigation because of access issues resulting from construction in the area. Measurement sites included locations along the river, at points of inflow to the river, and at a point of outflow from the river. The USGS station identification and station name and the river mile associated with each measurement location are presented in table 1. River miles are referenced upstream from the Rio Grande confluence with the Gulf of Mexico; for example, site 34, Rio Grande at El Paso, Tex., is designated as river mile 1,249.9 (Hendricks, 1964). The relative locations of measurement sites are shown in figure 2.

Inflows to the river included municipal and industrial discharge of effluent, agricultural drain flows, reservoir outflows, and discharge of water from other sources. Effluent from WWTPs discharged to the river at four locations: sites 9, 18A, 21A, and 30 (fig. 2; at river miles 1,295.4; 1,275.7; $1,270.5$; and 1,251.0, respectively). Drains, which collect groundwater return flow at locations where the water table is at a higher elevation than the bottom of the drain channel, discharged to the river at sites $3,11,15,18,20,24$, and 32 (at river miles $1,307.6 ; 1,291.8 ; 1,283.6 ; 1,276.6 ; 1,271.6 ; 1,265.4$; and 1,250.3, respectively). Flow from Keystone Reservoir, El Paso, Tex. (site 33), enters the river at river mile 1,250.1; however, there was no measurable streamflow during the study. Inflows from other sources included stormwater inflows, unspecified pipe inflows, and other sources within the study reach. These inflow locations (sites 6, 14A, 23, 32A, and 33A) entered the study reach at river miles $1,301.2 ; 1,287.3 ; 1,268.4$; $1,250.2$; and 1,250.0, respectively. Outflow from the river was limited to a single point of diversion at the Mesilla West Side Canal (site 12A, river mile 1,290.0). 
Table 1. Locations of U.S. Geological Survey Rio Grande seepage investigation streamflow measurement sites from below Leasburg Dam, Leasburg, New Mexico, to above El Paso, Texas, April 3-4, 2018.

[ID, identification number; USGS, U.S. Geological Survey; NAD 83, North American Datum of 1983; NM, New Mexico; WWTP, wastewater treatment plant; TX, Texas; WW, wastewater]

\begin{tabular}{|c|c|c|c|c|c|c|c|}
\hline $\begin{array}{l}\text { Site ID } \\
\text { (see } \\
\text { fig. 1) }\end{array}$ & USGS station ID & Station name & Site type & $\begin{array}{l}\text { Latitude } \\
\text { (NAD 83) }\end{array}$ & $\begin{array}{l}\text { Longitude } \\
\text { (NAD 83) }\end{array}$ & $\begin{array}{l}\text { River } \\
\text { mile }^{1}\end{array}$ & $\begin{array}{c}\text { Years of site inclusion in } \\
\text { seepage investigation during } \\
2006-2018\end{array}$ \\
\hline 1 & 322841106551010 & Rio Grande below Leasburg Dam, NM & Main stem & 32.4769 & -106.9197 & $1,312.3$ & $2006-2009,2012-2015,2018$ \\
\hline 2 & 322721106540810 & Rio Grande near Leasburg, NM & Main stem & 32.4544 & -106.9017 & $1,310.2$ & 2006-2009, 2012-2015, 2018 \\
\hline 3 & 322541106525110 & Selden Drain at Levee Road near Leasburg, NM & Inflow & 32.4281 & -106.8814 & $1,307.6$ & 2006-2009, 2012-2015, 2018 \\
\hline 4 & 322505106520110 & Rio Grande near Hill, NM & Main stem & 32.4186 & -106.8672 & $1,306.3$ & 2006-2009, 2012-2015, 2018 \\
\hline 5 & 322234106511710 & Rio Grande at Shalem Bridge near Dona Ana, NM & Main stem & 32.3762 & -106.8553 & $1,302.7$ & 2006-2009, 2012-2015, 2018 \\
\hline 6 & 322214106501410 & Spillway Number 5 near Dona Ana, NM & Inflow & 32.3703 & -106.8381 & $1,301.2$ & 2006-2009, 2012-2015, 2018 \\
\hline 7 & 322018106500910 & Rio Grande near Picacho, NM & Main stem & 32.3383 & -106.8367 & $1,298.8$ & 2006-2009, 2012-2015, 2018 \\
\hline 8 & 321745106492510 & Rio Grande below Picacho Bridge near Las Cruces, NM & Main stem & 32.2964 & -106.8242 & $1,295.6$ & 2006-2009, 2012-2015, 2018 \\
\hline 9 & 321735106492610 & Las Cruces WWTP Outfall, Las Cruces, NM & Inflow & 32.2928 & -106.8247 & $1,295.4$ & 2006-2009, 2012-2015, 2018 \\
\hline 10 & 321549106492910 & Rio Grande at NM-359 Bridge near Mesilla, NM & Main stem & 32.2637 & -106.8253 & $1,293.1$ & 2006-2009, 2012-2015, 2018 \\
\hline 11 & 321434106485610 & Picacho Drain above Mesilla Dam, NM & Inflow & 32.2422 & -106.8153 & $1,291.8$ & 2006-2009, 2012-2015, 2018 \\
\hline 12 & 321430106484910 & Rio Grande below Picacho Drain, NM & Main stem & 32.2419 & -106.8142 & $1,291.7$ & 2006-2009, 2012-2015, 2018 \\
\hline $12 \mathrm{~A}$ & 321332106474910 & Mesilla West Side Canal at Diversion near Las Cruces, NM & Outflow & 32.2256 & -106.7969 & $1,290.0$ & 2018 \\
\hline 13 & 321317106471510 & Rio Grande below Mesilla Dam near Santo Tomas, NM & Main stem & 32.2211 & -106.7886 & $1,289.5$ & 2006-2009, 2012-2015, 2018 \\
\hline 14 & 321224106453210 & Rio Grande at NM-28 Bridge near San Pablo, NM & Main stem & 32.2067 & -106.7597 & $1,287.3$ & 2006-2009, 2012-2015, 2018 \\
\hline $14 \mathrm{~A}$ & 321131106441410 & Wasteway below NM28, San Pablo & Inflow & 32.1919 & -106.7372 & $1,287.3$ & 2014-2015, 2018 \\
\hline 15 & 321014106431410 & Santo Tomas River Drain at Levee Road near San Miguel, NM & Inflow & 32.1707 & -106.7211 & $1,283.6$ & 2006-2009, 2012-2015, 2018 \\
\hline 16 & 320943106425810 & Rio Grande NM-192 Bridge near San Miguel, NM & Main stem & 32.1620 & -106.7167 & $1,282.7$ & 2006-2009, 2012-2015, 2018 \\
\hline 17 & 320648106400510 & Rio Grande at NM-189 Bridge near Vado, NM & Main stem & 32.1136 & -106.6689 & $1,277.8$ & 2006-2009, 2012-2015, 2018 \\
\hline 18 & 320610106393110 & Del Rio Drain at Levee Road near Vado, NM & Inflow & 32.1029 & -106.6592 & $1,276.6$ & 2006-2009, 2012-2015, 2018 \\
\hline $18 \mathrm{~A}$ & 320525106393410 & Dona Ana County South Central WWTP Outfall near Vado, NM & Inflow & 32.0903 & -106.6600 & $1,275.7$ & 2006-2009, 2012-2015, 2018 \\
\hline 19 & 320356106394510 & Rio Grande at NM-226 Bridge near Berino, NM & Main stem & 32.0656 & -106.6633 & $1,273.8$ & 2006-2009, 2012-2015, 2018 \\
\hline 20 & 320214106392510 & La Mesa Drain at Levee Road near Chamberino, NM & Inflow & 32.0373 & -106.6575 & $1,271.6$ & 2006-2009, 2012-2015, 2018 \\
\hline 21 & 320212106391810 & Rio Grande below La Mesa Drain near Chamberino, NM & Main stem & 32.0369 & -106.6561 & $1,271.5$ & 2006-2009, 2012-2015, 2018 \\
\hline $21 \mathrm{~A}$ & 320122106385610 & Anthony WWTP Outfall at NM-186 Bridge near Anthony, NM & Inflow & 32.0228 & -106.6489 & $1,270.5$ & $2009,2012-2015,2018$ \\
\hline 22 & 315958106380710 & Rio Grande at NM-225 Bridge near Anthony, NM & Main stem & 31.9994 & -106.6361 & $1,268.5$ & $2006-2015,2018$ \\
\hline 23 & 315957106380610 & Pipe Inflow at NM-225 Bridge near Anthony, NM & Inflow & 31.9992 & -106.6353 & $1,268.4$ & $2006-2015,2018$ \\
\hline 24 & 315807106361910 & East Side Drain at Levee Road near Anthony, TX & Inflow & 31.9687 & -106.6058 & $1,265.4$ & 2006-2015, 2018 \\
\hline
\end{tabular}




\begin{tabular}{|c|c|c|c|c|c|c|c|}
\hline $\begin{array}{l}\text { Site ID } \\
\text { (see } \\
\text { fig. 1) }\end{array}$ & USGS station ID & Station name & Site type & $\begin{array}{l}\text { Latitude } \\
\text { (NAD 83) }\end{array}$ & $\begin{array}{l}\text { Longitude } \\
\text { (NAD 83) }\end{array}$ & $\begin{array}{l}\text { River } \\
\text { mile }^{1}\end{array}$ & $\begin{array}{c}\text { Years of site inclusion in } \\
\text { seepage investigation during } \\
2006-2018\end{array}$ \\
\hline 25 & 315733106361610 & Rio Grande at Vinton Bridge near Vinton, TX & Main stem & 31.9594 & -106.6050 & $1,264.7$ & $2006-2015,2018$ \\
\hline 26 & 315454106360610 & Rio Grande at TX-259 Bridge, Canutillo, TX & Main stem & 31.9153 & -106.6022 & $1,261.6$ & 2006-2015, 2018 \\
\hline 27 & 315309106355510 & Rio Grande at Borderland Bridge near Borderland, TX & Main stem & 31.8861 & -106.5989 & $1,259.3$ & 2006-2015, 2018 \\
\hline 28 & 315046106361810 & Rio Grande at TX-260 Bridge near Santa Teresa, NM & Main stem & 31.8464 & -106.6058 & $1,256.2$ & $2006-2015,2018$ \\
\hline $28 \mathrm{~A}$ & 314924106355410 & Montoya A Lateral WW 36 near El Paso, TX & Inflow & 31.8232 & -106.5983 & $1,252.8$ & 2018 \\
\hline 29 & 314824106345710 & Rio Grande near Sunland Park, NM & Main stem & 31.8067 & -106.5828 & $1,254.3$ & $2006-2015,2018$ \\
\hline 30 & 314755106332510 & Sunland Park WWTP Outfall, Sunland Park, NM & Inflow & 31.7986 & -106.5575 & $1,251.0$ & 2006-2015, 2018 \\
\hline 31 & 314756106331610 & Rio Grande at Sunland Park Bridge Sunland Park, NM & Main stem & 31.7989 & -106.5550 & $1,250.9$ & 2006-2015, 2018 \\
\hline 32 & 314810106324610 & Montoya Drain at Sunland Park, NM & Inflow & 31.8029 & -106.5467 & $1,250.3$ & 2006-2015, 2018 \\
\hline $32 \mathrm{~A}$ & 314812106324410 & El Paso Electric River Outfall, Sunland Park, NM & Inflow & 31.8036 & -106.5461 & $1,250.2$ & $2006-2015,2018$ \\
\hline 33 & 314818106323910 & Keystone Reservior Inlet, El Paso, TX & Inflow & 31.8050 & -106.5444 & $1,250.1$ & 2006-2015, 2018 \\
\hline $33 \mathrm{~A}$ & 314813106322810 & Side-Channel Inlet above Courchesne Bridge, El Paso, TX & Inflow & 31.8036 & -106.5417 & $1,250.0$ & 2006-2015, 2018 \\
\hline 34 & 08364000 & Rio Grande at El Paso, TX & Main stem & 31.8029 & -106.5408 & $1,249.9$ & $2006-2015$ \\
\hline
\end{tabular}

${ }^{1}$ River miles are referenced upstream from the Rio Grande confluence with the Gulf of Mexico (Hendricks, 1964). 

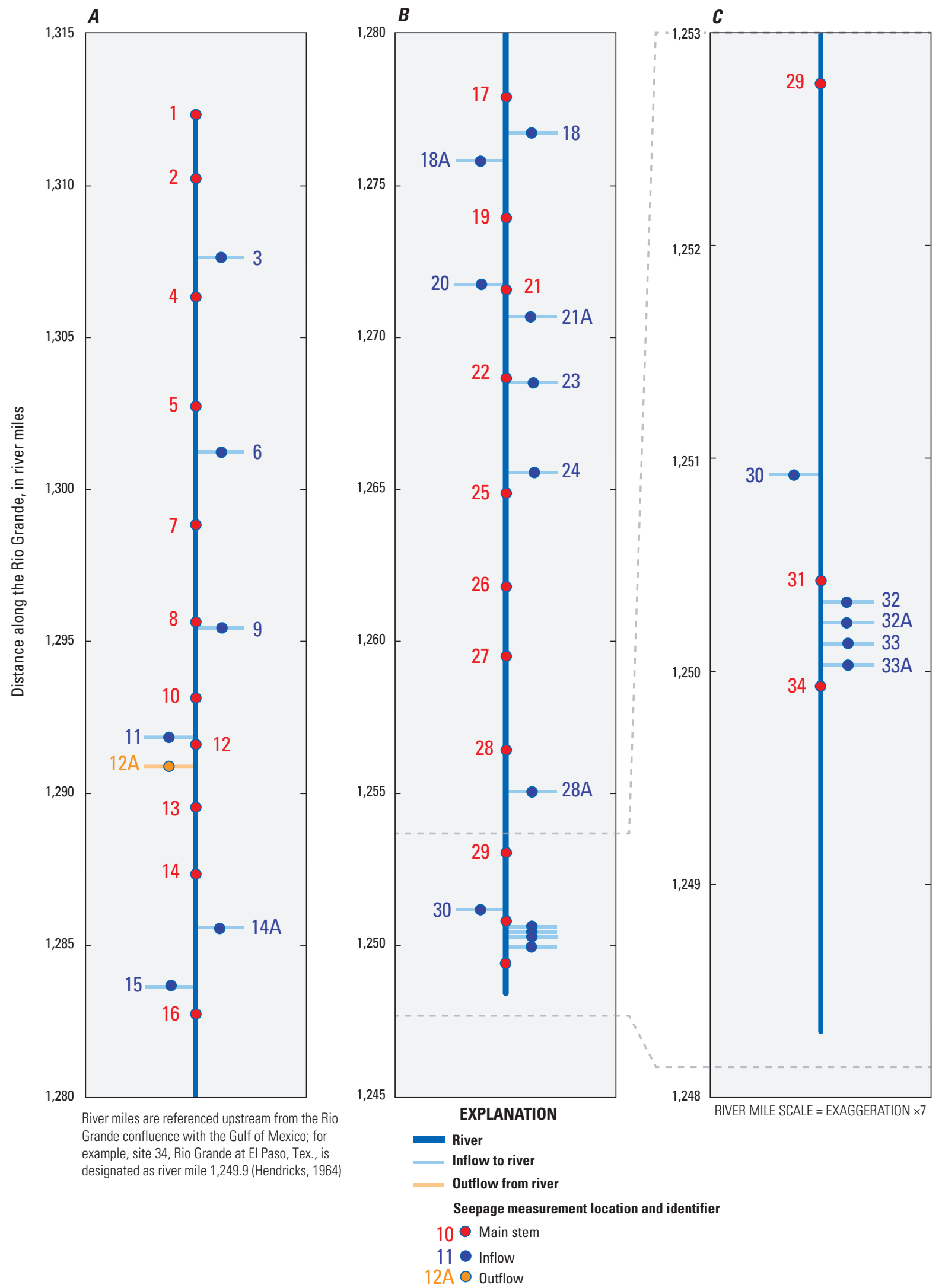

Figure 2. Measurement locations for U.S. Geological Survey Rio Grande seepage investigation from below Leasburg Dam, Leasburg, New Mexico, to above El Paso, Texas, 2018, and the locations of inflows to the river within the study reach. $A$, Locations of measurement sites 1-16. B, Locations of measurement sites 17-34. C, An expanded view of the locations of measurement sites 29-34. 


\section{Methods}

The methods section outlines the general approach used in conducting the seepage investigation. Methods for measuring streamflow and discharge from WWTPs are described along with computation methods for estimating seepage gains and losses.

\section{General Approach}

From 1988 to 1998 and 2006 to 2015, seepage investigations were conducted over a period of 1-2 days in February of each year, during no-flow or low-flow conditions in the non-irrigation season. The 2018 seepage investigation was conducted during April 3-4, during bankfull conditions caused by releases from Caballo Dam to the Rio Grande for the purpose of downstream agricultural irrigation. During the seepage investigation, streamflow was measured at sites along the river, at inflows to the river, and at an outflow from the river. Measurement locations (table 1) have remained fairly consistent from year to year, with minor site additions or removals based on conditions observed in the field. Streamflow measurements were collected over an approximate 10-hour period beginning at about 8 a.m. and ending at about 6 p.m. on each of the 2 days.

Net seepage gain or loss was computed for each subreach by subtracting the streamflow measured at the upstream location and any inflow to the river within the subreach from the streamflow measured at the downstream location along the river and any outflow from the river within the subreach. Surface inflows to the river were considered contributions and not seepage gains. Surface outflows from the river were considered diversions and not seepage losses. Seepage gain or loss was considered to be meaningful for subreaches where the computed net seepage gain or loss exceeded the cumulative measurement uncertainty for the computation (see section "Seepage Computation").

Losses due to evaporation from the water surface and transpiration by vegetation were not estimated for this study. Computed gains or losses in streamflow for the seepage investigation presented in this report are assumed to be due to seepage to or from the streambed resulting from the interchange of surface water and groundwater.

\section{Measurement of Streamflow and Wastewater Treatment Plant Discharge}

Streamflow measurements (main-stem and non-WWTP sites) used in this seepage investigation were collected by USGS personnel using a variety of measurement techniques, depending on site characteristics. Instantaneous streamflow was measured using an acoustic
Doppler current profiler (ADCP) or a handheld acoustic Doppler velocimeter (ADV) (standard USGS protocols as described in Rantz and others, 1982; Nolan and Shields, 2000; Turnipseed and Sauer, 2010). Measurements were made using ADCPs when possible. Handheld ADVs were used when surface-water depths were too shallow to measure streamflow by using an ADCP. Streamflow measurements are reported in cubic feet per second and assigned a qualitative accuracy rating based on a field assessment of the uncertainty of the measurement (see section "Estimation of Uncertainty" for additional details).

Effluent from municipal and industrial WWTPs is discharged to the river in one of three ways: (1) as a discrete variable-flow (batch) release, (2) as a continuous equalized-flow (equalized) release, or (3) as a continuous variable-flow (unequalized) release. Discharge from a WWTP was reported as either the instantaneous discharge metered by the plant at a specific time (Reported-I) or as the daily mean discharge computed from the total discharge for the day metered by the plant (Reported-MDI); these two discharge measurement methods can be substantially different for WWTPs that batch release effluent. For the four WWTPs that discharged effluent to the river (sites 9, 18A, 21A, and 30), the most appropriate method of reporting discharge and the associated uncertainty in the reported measurement was assessed site by site on the basis of the way that effluent was released from the plant, as well as data availability. Of the four WWTPs included in the seepage investigation, one was a batch-release plant (site 18A), one was an equalized-release plant (site 9), and two were unequalized-release plants (sites $21 \mathrm{~A}$ and 30). Similar to streamflow measurements, discharge data for WWTPs are reported in cubic feet per second and assigned a qualitative accuracy rating based on a field assessment of the uncertainty of the measurement. Discharge data for sites $18 \mathrm{~A}, 21 \mathrm{~A}$, and 30 were provided by the plant and therefore designated as Reported-MDI with a measurement uncertainty greater than 8 percent. Discharge of plant effluent at site 9 was measured by USGS personnel at the riverside outfall and assigned a measurement uncertainty of less than or equal to 8 percent. No instantaneous metered discharge measurements were used; therefore, no measurements were designated as Reported-I during the 2018 seepage investigation. Hereafter, streamflow and discharge measurements collected for this study are collectively referred to as "streamflow measurements." 


\section{Seepage Computation}

Computations presented as part of the seepage investigations include net seepage gain or loss, estimation of uncertainty for each measurement, and determination of meaningful computed net seepage gain or loss.

\section{Net Seepage Gain or Loss}

The mass balance equation used for calculating net seepage gain or loss in a subreach is as follows (Simonds and Sinclair, 2002):

$$
Q_{S}=Q_{d s}-Q_{u s}-Q_{\text {in }}+Q_{\text {out }}
$$

where

$$
\begin{aligned}
& Q_{S} \quad \begin{array}{l}
\text { is the net seepage gain or loss for a subreach, } \\
\text { in cubic feet per second; }
\end{array} \\
& \begin{array}{c}
\text { is the streamflow measured at the downstream } \\
\text { end of the subreach, in cubic feet per }
\end{array} \\
& \text { second; } \\
& \begin{array}{c}
Q_{u s} \quad \text { is the streamflow measured at the upstream } \\
\text { end of the subreach, in cubic feet per } \\
\text { second; }
\end{array} \\
& Q_{\text {in }} \quad \begin{array}{l}
\text { is the sum of inflows in the subreach, in cubic } \\
\text { feet per second; and }
\end{array} \\
& Q_{\text {out }} \quad \begin{array}{l}
\text { is the sum of outflows in the subreach, in } \\
\text { cubic feet per second. }
\end{array}
\end{aligned}
$$

The result is the estimated net flux of water gained or lost from the streambed for the subreach. If the sum of $Q_{d s}$ and $Q_{o u t}$ is less than the sum of $Q_{u s}$ and $Q_{i n}$-that is, if less streamflow was measured at the downstream section of the subreach than was measured at the upstream section while accounting for any inflow or outflow to that subreach (eq. 1) - then the algebraic sign of the net seepage is negative $(-)$, which signifies a loss of water from the subreach. Conversely, if the sum of $Q_{d s}$ and $Q_{\text {out }}$ is greater than the sum of $Q_{u s}$ and $Q_{i n}$, then the algebraic sign of the net seepage is positive $(+)$, which signifies a gain of water to that subreach. For example, in this investigation, the net seepage gain or loss for subreach 17 to 19 was computed as 105 cubic feet per second $\left(\mathrm{ft}^{3} / \mathrm{s}\right)\left(Q_{S}\right)$, which is the difference between the measured streamflow of $577 \mathrm{ft}^{3} / \mathrm{s}$ at site $17\left(Q_{d}\right)$ and the measured discharge of $683 \mathrm{ft}^{3} / \mathrm{s}$ at site $19\left(Q_{u s}\right)$, minus the measured inflow of $0.63 \mathrm{ft}^{3} / \mathrm{s}$ at site $18 \mathrm{~A}\left(Q_{i n}\right)($ table 2$)$.

\section{Estimation of Uncertainty}

Individual streamflow measurements were assigned a qualitative accuracy rating that represents the percentage of uncertainty in an individual measurement and was based on a subjective evaluation of the measurement uncertainty made by the hydrographer on the basis of multiple factors that could affect the quality of the measurement (Sauer and Meyer, 1992). These factors include the instrumentation used, number and distribution of vertical sections where velocity is measured, estimation of average velocity, uniformity of streamflow, regularity and firmness of channel bottom, steadiness of stage and discharge during the measurement, and presence or absence of wind or debris in the streamflow that could affect the ability of the meter to accurately measure the streamflow velocity (Wilberg and Stolp, 2005). 
Table 2. Summary of measured streamflow and the computed net seepage gain or loss in streamflow in subreaches, Rio Grande seepage investigation, April 3-4, 2018.

[Site number: See table 1 and figures 1 and 2 for location of sites; $Q_{u s}$, streamflow measured at upstream river channel site; $\mathrm{ft}^{3} / \mathrm{s}$, cubic foot per second; \pm , plus or minus; $Q_{i n}$, streamflow measured at inflow site,

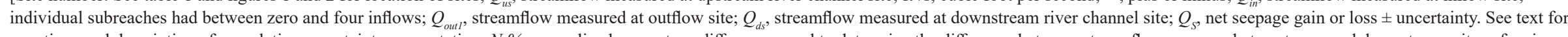

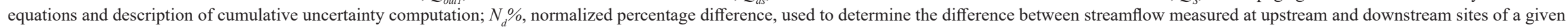

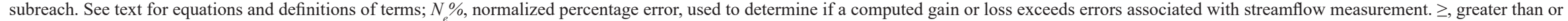
equal to; Y, yes; N, no; \%, percentage; - , not applicable]

\begin{tabular}{|c|c|c|c|c|c|c|c|c|c|c|c|c|c|c|}
\hline Subreach $^{1}$ & $\begin{array}{l}\text { Sites included } \\
\text { in subreach }\end{array}$ & $\begin{array}{l}\text { Distance } \\
\text { (miles) }\end{array}$ & $\begin{array}{c}\text { Sample } \\
\text { date }\end{array}$ & $\begin{array}{c}\boldsymbol{Q}_{u s} \text { with } \\
\text { percentage } \\
\text { of mea- } \\
\text { surement } \\
\text { uncertainty } \\
\text { in parenthe- } \\
\text { ses }\left(\mathrm{ft}^{3} / \mathrm{s}\right)\end{array}$ & $\begin{array}{c}\boldsymbol{Q}_{i n 1} \text { with } \\
\text { percentage } \\
\text { of mea- } \\
\text { surement } \\
\text { uncertainty } \\
\text { in parenthe- } \\
\text { ses }\left(\mathrm{ft}^{3} / \mathrm{s}\right)\end{array}$ & $\begin{array}{c}\boldsymbol{Q}_{\text {in2 }} \text { with } \\
\text { percentage } \\
\text { of mea- } \\
\text { surement } \\
\text { uncertainty } \\
\text { in parenthe- } \\
\text { ses }\left(\mathrm{ft}^{3} / \mathrm{s}\right)\end{array}$ & $\begin{array}{c}\boldsymbol{Q}_{i n 3} \text { with } \\
\text { percentage } \\
\text { of mea- } \\
\text { surement } \\
\text { uncertainty } \\
\text { in parenthe- } \\
\text { ses }\left(\mathrm{ft}^{3} / \mathrm{s}\right)\end{array}$ & $\begin{array}{c}\boldsymbol{Q}_{\text {ind }} \text { with } \\
\text { percentage } \\
\text { of mea- } \\
\text { surement } \\
\text { uncertainty } \\
\text { in parenthe- } \\
\text { ses }\left(\mathrm{ft}^{3} / \mathrm{s}\right)\end{array}$ & $\begin{array}{c}\boldsymbol{Q}_{\text {outt }} \text { with } \\
\text { percentage } \\
\text { of mea- } \\
\text { surement } \\
\text { uncertainty } \\
\text { in parenthe- } \\
\text { ses }\left(\mathrm{ft}^{3} / \mathrm{s}\right)\end{array}$ & $\begin{array}{c}\boldsymbol{Q}_{d s} \text { with } \\
\text { percentage } \\
\text { of mea- } \\
\text { surement } \\
\text { uncertainty } \\
\text { in parenthe- } \\
\text { ses }\left(\mathrm{ft}^{3} / \mathrm{s}\right)\end{array}$ & $\begin{array}{c}\boldsymbol{Q}_{s} \\
\left(\mathrm{ft}^{3} / \mathrm{s}\right)\end{array}$ & $\mathbf{N}_{d} \%$ & $\mathbf{N}_{e} \%$ & $\begin{array}{c}\boldsymbol{N}_{d} \% \geq \\
\boldsymbol{N}_{e} \% \\
\left(\mathrm{Y}_{\text {or }}\right. \\
\mathbf{N})\end{array}$ \\
\hline 1 to 2 & 1,2 & 2.1 & $4 / 3 / 2018$ & $917(10 \%)$ & - & - & - & - & - & $1,000(10 \%)$ & $83 \pm 136$ & 8.3 & 13.6 & $\mathrm{~N}$ \\
\hline 2 to 4 & $2,3,4$ & 3.9 & $4 / 3 / 2018$ & $1,000(10 \%)$ & $0(0 \%)$ & - & - & - & - & $822(10 \%)$ & $-178 \pm 129$ & 17.8 & 12.9 & $\mathrm{Y}$ \\
\hline 4 to 5 & 4,5 & 3.6 & $4 / 3 / 2018$ & $822(10 \%)$ & - & - & - & - & - & $842(10 \%)$ & $20 \pm 118$ & 2.4 & 14.0 & $\mathrm{~N}$ \\
\hline 5 to 7 & $5,6,7$ & 3.9 & $4 / 3 / 2018$ & $842(10 \%)$ & $0(0 \%)$ & - & - & - & - & $801(10 \%)$ & $-41 \pm 116$ & 4.9 & 13.8 & $\mathrm{~N}$ \\
\hline 7 to 8 & 7,8 & 3.2 & $4 / 3 / 2018$ & $801(10 \%)$ & - & - & - & - & - & $961(8 \%)$ & $160 \pm 111$ & 16.6 & 11.6 & $\mathrm{Y}$ \\
\hline 8 to 10 & $8,9,10$ & 2.5 & $4 / 3 / 2018$ & $961(8 \%)$ & $12.7(8 \%)$ & - & - & - & - & $892(8 \%)$ & $-81.7 \pm 105$ & 8.5 & 10.9 & $\mathrm{~N}$ \\
\hline 10 to 12 & $10,11,12$ & 1.4 & $4 / 3 / 2018$ & $892(8 \%)$ & $0(0 \%)$ & - & - & - & - & $821(8 \%)$ & $-71 \pm 97$ & 8.0 & 10.9 & $\mathrm{~N}$ \\
\hline 12 to 13 & $12,12 \mathrm{~A}, 13$ & 2.2 & $4 / 3 / 2018$ & $821(8 \%)$ & - & - & - & - & $127(8 \%)$ & $583(10 \%)$ & $-111 \pm 88$ & 13.5 & 10.8 & $\mathrm{Y}$ \\
\hline 13 to 14 & 13,14 & 2.2 & $4 / 3 / 2018$ & $583(10 \%)$ & - & - & - & - & - & $756(8 \%)$ & $173 \pm 84$ & 22.9 & 11.1 & $\mathrm{Y}$ \\
\hline 14 to 16 & $14,14 \mathrm{~A}, 15,16$ & 4.6 & $4 / 3 / 2018$ & $756(8 \%)$ & $0(0 \%)$ & $0(0 \%)$ & - & - & - & $586(10 \%)$ & $-170 \pm 84$ & 22.5 & 11.1 & $\mathrm{Y}$ \\
\hline 16 to 17 & 16,17 & 4.9 & $4 / 3 / 2018$ & $586(10 \%)$ & - & - & - & - & - & $577(10 \%)$ & $-9 \pm 82$ & 1.4 & 14.0 & $\mathrm{~N}$ \\
\hline 17 to 19 & $17,18,18 \mathrm{~A}, 19$ & 4.0 & $4 / 3 / 2018$ & $577(10 \%)$ & 0.63 & - & - & - & - & $683(8 \%)$ & $105 \pm 79$ & 14.5 & 11.6 & $\mathrm{Y}$ \\
\hline 19 to $21^{2}$ & $19,20,21$ & 2.3 & $4 / 4 / 2018$ & $683(8 \%)$ & $0(0 \%)$ & - & - & - & - & $676(10 \%)$ & $-7 \pm 87$ & 1.0 & 12.7 & $\mathrm{~N}$ \\
\hline 21 to 22 & $21,21 \mathrm{~A}, 22$ & 3.4 & $4 / 4 / 2018$ & $676(10 \%)$ & $0(0 \%)$ & - & - & - & - & $733(8 \%)$ & $57 \pm 89$ & 7.8 & 12.2 & $\mathrm{~N}$ \\
\hline 22 to 25 & $22,23,24,25$ & 3.4 & $4 / 4 / 2018$ & $733(8 \%)$ & $0(0 \%)$ & $0(0 \%)$ & - & - & - & $834(5 \%)$ & $101 \pm 72$ & 12.1 & 8.6 & $\mathrm{Y}$ \\
\hline 25 to 26 & 25,26 & 3.1 & $4 / 4 / 2018$ & $834(5 \%)$ & - & - & - & - & - & $693(5 \%)$ & $-141 \pm 54$ & 16.9 & 6.5 & $\mathrm{Y}$ \\
\hline 26 to 27 & 26,27 & 2.3 & $4 / 4 / 2018$ & $693(5 \%)$ & - & - & - & - & - & $762(8 \%)$ & $69 \pm 70$ & 9.1 & 9.2 & $\mathrm{~N}$ \\
\hline 27 to 28 & 27,28 & 3.1 & $4 / 4 / 2018$ & $762(8 \%)$ & - & - & - & - & - & $662(8 \%)$ & $-100 \pm 81$ & 13.1 & 10.6 & $\mathrm{Y}$ \\
\hline 28 to 29 & $28,28 \mathrm{~A}, 29$ & 3.4 & $4 / 4 / 2018$ & $662(8 \%)$ & $5.92(5 \%)$ & - & - & - & - & $744(8 \%)$ & $76 \pm 80$ & 10.0 & 10.7 & $\mathrm{~N}$ \\
\hline 29 to 31 & $29,30,31$ & 1.9 & $4 / 4 / 2018$ & $744(8 \%)$ & $1.71(10 \%)$ & & - & - & - & $699(8 \%)$ & $-47 \pm 82$ & 7.0 & 11.0 & $\mathrm{~N}$ \\
\hline 31 to 34 & $\begin{array}{c}31,32,32 \mathrm{~A} \\
33,34\end{array}$ & 1.0 & $4 / 4 / 2018$ & $699(8 \%)$ & $1.17(8 \%)$ & $21.8(10 \%)$ & $0(0 \%)$ & $0(0 \%)$ & $0(\%)$ & $777(8 \%)$ & $55 \pm 84$ & 7.1 & 10.8 & $\mathrm{~N}$ \\
\hline
\end{tabular}

${ }^{1}$ Subreach is defined as the interval between two adjacent main-stem streamflow-measurement locations.

${ }^{2}$ Site 19 measured on April 3, 2018. Site 21 measured on April 4, 2018. $Q_{S}$ for this subreach should be treated with caution when interpreting meaningful gain or loss. 
The uncertainty in the streamflow measurement was assigned a numerical value, derived from the qualitative accuracy rating, as follows: excellent, 2 percent; good, 5 percent; fair, 8 percent; and poor, 10 percent, where the percent error is applied to the measured flow. If there was no measurable streamflow at a site, then the uncertainty for the individual measurement was zero, and the individual uncertainty did not contribute numerically to the cumulative uncertainty estimation of the seepage computation for the subreach.

The cumulative uncertainty estimation associated with the computed net seepage gain or loss for a subreach was determined using the following equation modified from Wheeler and Eddy-Miller (2005):

$$
\delta Q_{S}=\sqrt{\left(a_{1} Q_{1}\right)^{2}+\left(a_{2} Q_{2}\right)^{2} \ldots+\left(a_{n} Q_{n}\right)^{2}}
$$

where

$$
\begin{aligned}
& \delta Q_{S} \quad \text { is the cumulative uncertainty in the } \\
& a_{n} \quad \text { is the uncertainty of a measurement, in } \\
& \text { percent; and } \\
& Q_{n} \quad \text { is the measured streamflow, in cubic feet } \\
& \text { per second. }
\end{aligned}
$$

For example, in this investigation, the measurement uncertainty of the individual streamflow measurement for site 31 was plus or minus $( \pm) 55.9 \mathrm{ft}^{3} / \mathrm{s}\left(a_{l} Q_{l}\right)$, computed as the product of the streamflow measurement of $699 \mathrm{ft}^{3} / \mathrm{s}\left(Q_{1}\right)$ and the measurement accuracy rating of 8 percent $\left(a_{1}\right)$ (table 2 ). The cumulative measurement uncertainty associated with the net seepage gain or loss for subreach 31 to 34 was $\pm 84 \mathrm{ft}^{3} / \mathrm{s}$ $\left(\delta Q_{S}\right)$, computed as the square root of the sum of the squares of the measurement uncertainties for site $31, \pm 55.9 \mathrm{ft}^{3} / \mathrm{s}$ $\left(a_{1} Q_{1}\right) ;$ site $32, \pm 0.094 \mathrm{ft}^{3} / \mathrm{s}\left(a_{2} Q_{2}\right) ;$ site $32 \mathrm{~A}, \pm 2.2 \mathrm{ft}^{3} / \mathrm{s}\left(a_{3} Q_{3}\right) ;$ and site $34, \pm 62.2 \mathrm{ft}^{3} / \mathrm{s}\left(a_{4} Q_{4}\right)$.

\section{Determination of Meaningful Computed Seepage Gain or Loss}

Shallow water depths, an unstable and moving river bed, and poor channel conditions can result in increased uncertainties (exceeding 8 percent) in the computation of net seepage gains and losses. In some cases, the cumulative measurement uncertainty can exceed the net seepage gain or loss computed for a subreach. An estimated gain or loss was determined to be meaningful when it exceeded the cumulative measurement uncertainty associated with the net seepage computation. For the determination of meaningful gain or loss, the net seepage gain or loss and the cumulative measurement uncertainty were normalized to allow for comparison between subreaches with varying discharges and for comparison of a particular subreach in different years. The percentage of normalized seepage gain or loss and normalized cumulative uncertainty were computed for each subreach by using the following equations modified from Wilberg and Stolp (2005):

$$
N_{d}=\left|\frac{Q_{S}}{\operatorname{Max}\left[\left(Q_{u s}+Q_{\text {in }}\right),\left(Q_{d s}+Q_{\text {out }}\right)\right]}\right| \times 100
$$

where

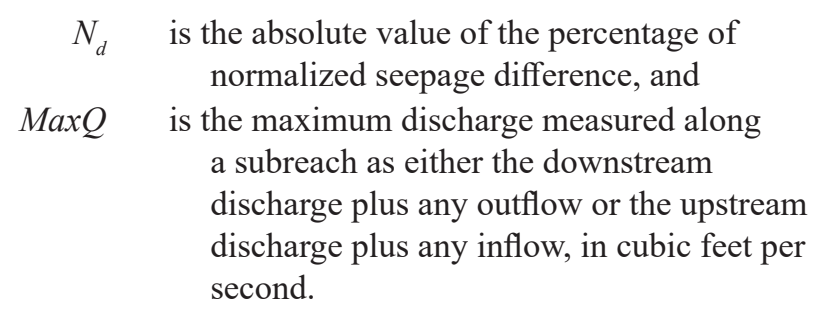

$$
N_{e}=\left|\frac{\delta Q_{S}}{\operatorname{Max}\left[\left(Q_{u s}+Q_{\text {in }}\right),\left(Q_{d s}+Q_{\text {out }}\right)\right]}\right| \times 100
$$

where

$$
\begin{gathered}
N_{e} \quad \text { is the absolute value of the percentage of } \\
\text { normalized cumulative uncertainty. }
\end{gathered}
$$

A computed gain or loss for a subreach was considered meaningful if the percentage of normalized seepage difference $\left(N_{d}\right)$ was greater than or equal to the percentage of normalized cumulative uncertainty $\left(N_{e}\right)$. For example, the estimated seepage gain $\left(Q_{S}\right)$ for subreach 7 to 8 is $160 \pm 111 \mathrm{ft}^{3} / \mathrm{s}$ (table 2 ). This gain, as a percentage of the normalized seepage difference $\left(N_{d}\right)$, is 16.6 percent of the maximum streamflow (sum of upstream streamflow and inflow) and is greater than the percentage of normalized cumulative uncertainty $\left(N_{e}\right)$ of 11.6 percent, indicating that the gain is meaningful.

\section{Seepage Investigation}

The 2018 seepage investigation was conducted on April 3-4 on a 62.4-mile reach of the Rio Grande and included 41 measurement locations from site 1 in Leasburg, N. Mex., to site 34 in El Paso, Tex. (fig. 1, table 1). Caballo Dam began releasing water on March 13 (EBID, 2018). The study reach had sustained flows for about 22 days prior to the investigation to allow channel conditions, including bank storage, to equilibrate. The seepage investigation occurred after initial releases for wetup and prior to irrigation diversions by EBID; consequently, the study reach had relatively high flow conditions compared to previous investigations, which occurred during non-irrigation season(s) in addition to the very few inflows and outflows.

To avoid changes in flow due to changes in releases or diversions, the seepage investigation was coordinated with planned irrigation demands. According to continuous data maintained by EBID (2018), releases from Caballo Dam were maintained at approximately $1,090 \mathrm{ft}^{3} / \mathrm{s}$ in the days leading up to the investigation. There was a $50 \mathrm{ft}^{3} / \mathrm{s}$ decrease in these releases recorded on the afternoon of April 3, but because of traveltimes, that change did not affect the investigation. This conclusion was reached by observing flows recorded at the 
USGS Leasburg river gage located at the farthest upstream measurement location (site 1) and the EBID Mesilla Dam gage located near site 13 .

In order to minimize the possible effects of unsteady flow on the investigation, streamflow measurements were planned with anticipated traveltimes where possible. Repeat measurements at the start and close of the investigation were made at select sites to ensure that fluctuations in streamflow did not exceed the measurement uncertainty.

Sites 1 through 19 were measured on April 3, 2018, whereas sites 20 through 34 were measured on April 4, 2018. There was measurable streamflow at 31 of the 41 measurement locations: 22 river sites, 8 inflow sites, and 1 outflow site (table 3). Uncertainty in the streamflow measurements ranged from 0 to 10 percent throughout the study reach. Average air temperature during the 2018 seepage investigation was 64 degrees Fahrenheit (National Climatic Data Center, 2018). The maximum air temperature was 79 degrees Fahrenheit on April 3 and 78 degrees Fahrenheit on April 4 (National Climatic Data Center, 2018). No precipitation was recorded at El Paso International Airport during the week prior to the seepage investigation (National Climatic Data Center, 2018) or during the seepage investigation. Therefore, precipitation was assumed to have not affected streamflow during this seepage investigation.

Net seepage gain or loss in the river and the associated cumulative uncertainty were computed for the 21 subreaches (table 2). Site 19 was measured on April 3, whereas site 21 was measured on April 4. The computed seepage for the subreach 19 to 21 is reported and believed to be reasonable, but caution is encouraged when interpreting meaningful gain or loss. The computed net seepage was less than the cumulative uncertainty at 12 of the 21 subreaches ( 1 to 2 , 4 to 5,5 to 7,8 to 10,10 to 12,16 to 17,19 to 21,21 to 22 , 26 to 27,28 to 29,29 to 31 , and 31 to 34 ), indicating that the estimated gain or loss cannot be considered meaningful within these subreaches. However, these seepage values and corresponding errors were included in the computation of the cumulative gain or loss for the entire study reach. Shallow water depths, moving sand bottom, and other poor channel conditions resulted in high uncertainties (at least 8 percent uncertainty in 20 out of 21 subreaches) in the computation of net seepage gains and losses. Previous investigations occurred during periods of little to no flow within the river, whereas the 2018 investigation occurred during bankfull conditions. The cumulative uncertainty error associated with the 2018 study is much larger than those associated with the previous investigations despite similar qualitative uncertainty measurement ratings among studies (excellent, good, fair, poor). The measured cumulative seepage loss in the Rio Grande in the 62.4-mile study reach in 2018 was $-55.7 \mathrm{ft}^{3} / \mathrm{s}$. The seepage loss was less than the error of \pm $111.3 \mathrm{ft}^{3} / \mathrm{s}$ computed for the flow at the top and bottom of the study reach along with the inputs and diversions (table 4). The cumulative measurement uncertainty represents a range of seepage estimates from -167.0 to $55.6 \mathrm{ft}^{3} / \mathrm{s}\left(-55.7 \mathrm{ft}^{3} / \mathrm{s} \pm\right.$ $\left.111.3 \mathrm{ft}^{3} / \mathrm{s}\right)$. This range indicates that seepage estimates could represent a loss, no change, or a gain; however, most of the seepage values in subreaches represent a loss. Gaining and losing subreaches were equally distributed spatially across the study reach with 10 subreaches gaining water (4 determined to be meaningful gains) and 11 subreaches losing water (5 determined to be meaningful losses). All USGS seepage investigations in the Mesilla Basin have reported a net seepage loss, and the magnitude of the loss in 2018 is within the range of previous studies (table 4) (Crilley and others, 2013; Gunn and Roark, 2014; Briody and others, 2016a, 2016b). However, the river conditions in 2018 were unlike those in the preceding studies. High-flow bankfull conditions due to upstream irrigation releases characterized this study, whereas in past studies the study reach had no to low flow. Conducting future seepage investigations during periods of low and stable flow, similar to previous studies, would minimize the measurement error associated with the shifting sand bottom. 
[ID, identification number; MDT, mountain daylight time; $\mathrm{ft}^{3} / \mathrm{s}$, cubic foot per second; NM, New Mexico; ADCP, acoustic Doppler current profiler; ADV, acoustic Doppler velocimeter; - , not applicable; Reported-MDI, daily mean streamflow computed from the reported total daily streamflow; TX, Texas; E, excellent (less than or equal to 2 percent); G, good (less than or equal to 5 percent); F, fair (less than or equal to 8 percent); $\mathrm{P}$, poor (greater than 10 percent)]

\begin{tabular}{|c|c|c|c|c|c|c|c|c|c|}
\hline $\begin{array}{l}\text { Site } \\
\text { ID }\end{array}$ & USGS station ID & Station name & $\begin{array}{l}\text { Measure- } \\
\text { ment date }\end{array}$ & $\begin{array}{l}\text { Measure- } \\
\text { ment time } \\
\text { (MDT) }\end{array}$ & $\begin{array}{c}\text { Streamflow } \\
\text { measurement } \\
\left(\mathrm{ft}^{3} / \mathrm{s}\right)\end{array}$ & $\begin{array}{c}\text { Streamflow } \\
\text { measurement } \\
\text { type }\end{array}$ & $\begin{array}{c}\text { Qualitative accuracy } \\
\text { rating of streamflow } \\
\text { measurement }\end{array}$ & $\begin{array}{l}\text { Streamflow } \\
\text { conditions }\end{array}$ & $\begin{array}{l}\text { Channel } \\
\text { conditions }\end{array}$ \\
\hline 1 & 322841106551010 & Rio Grande below Leasburg Dam, NM & $4 / 3 / 2018$ & 9:54 a.m. & 917 & ADCP & $\mathrm{P}$ & Steady & Uneven, soft, sand \\
\hline 2 & 322721106540810 & Rio Grande near Leasburg, NM & $4 / 3 / 2018$ & 9:52 a.m. & 1,000 & $\mathrm{ADCP}$ & $\mathrm{P}$ & Steady & Uneven, soft, sand \\
\hline 3 & 322541106525110 & $\begin{array}{l}\text { Selden Drain at Levee Road near } \\
\text { Leasburg, NM }\end{array}$ & $4 / 3 / 2018$ & - & - & - & - & No flow & - \\
\hline 4 & 322505106520110 & Rio Grande near Hill, NM & $4 / 3 / 2018$ & 2:15 p.m. & 822 & $\mathrm{ADCP}$ & $P$ & Steady & Uneven, soft, sand \\
\hline 5 & 322234106511710 & $\begin{array}{l}\text { Rio Grande at Shalem Bridge near } \\
\text { Dona Ana, NM }\end{array}$ & $4 / 3 / 2018$ & 1:13 p.m. & 842 & $\mathrm{ADCP}$ & $\mathrm{P}$ & Steady & Uneven, soft, sand \\
\hline 6 & 322214106501410 & $\begin{array}{l}\text { Spillway Number } 5 \text { near Dona Ana, } \\
\text { NM }\end{array}$ & $4 / 3 / 2018$ & - & - & - & - & No flow & - \\
\hline 7 & 322018106500910 & Rio Grande near Picacho, NM & $4 / 3 / 2018$ & 3:51 p.m. & 801 & $\mathrm{ADCP}$ & $\mathrm{P}$ & Steady & Uneven, soft, sand \\
\hline 8 & 321745106492510 & $\begin{array}{l}\text { Rio Grande below Picacho Bridge near } \\
\text { Las Cruces, NM }\end{array}$ & $4 / 3 / 2018$ & 4:49 p.m. & 961 & $\mathrm{ADCP} / \mathrm{ADV}$ & $\mathrm{F}$ & Steady & Uneven, soft, sand \\
\hline 9 & 321735106492610 & $\begin{array}{l}\text { Las Cruces WWTP Outfall, Las } \\
\text { Cruces, NM }\end{array}$ & $4 / 3 / 2018$ & 2:15 p.m. & 12.7 & ADV & $\mathrm{F}$ & Steady & Uneven, soft, sand \\
\hline 10 & 321549106492910 & $\begin{array}{l}\text { Rio Grande at NM-359 Bridge near } \\
\text { Mesilla, NM }\end{array}$ & $4 / 3 / 2018$ & 8:12 a.m. & 892 & $\mathrm{ADCP}$ & $\mathrm{F}$ & Steady & Uneven, soft, sand \\
\hline 11 & 321434106485610 & Picacho Drain above Mesilla Dam, NM & $4 / 3 / 2018$ & - & - & - & - & No flow & - \\
\hline 12 & 321430106484910 & Rio Grande below Picacho Drain, NM & $4 / 3 / 2018$ & 2:29 p.m. & 821 & ADCP/ADV & $\mathrm{F}$ & Steady & Uneven, soft, sand \\
\hline $12 \mathrm{~A}$ & 321332106474910 & $\begin{array}{l}\text { Mesilla West Side Canal at Diversion } \\
\text { near Las Cruces, NM }\end{array}$ & $4 / 3 / 2018$ & 12:30 p.m. & 127 & $\mathrm{ADCP}$ & $\mathrm{F}$ & Steady & $\begin{array}{l}\text { Concrete-lined } \\
\text { ditch }\end{array}$ \\
\hline 13 & 321317106471510 & $\begin{array}{l}\text { Rio Grande below Mesilla Dam near } \\
\text { Santo Tomas, NM }\end{array}$ & $4 / 3 / 2018$ & 10:30 a.m. & 583 & $\mathrm{ADCP}$ & $P$ & Steady & Uneven, soft, sand \\
\hline 14 & 321224106453210 & $\begin{array}{l}\text { Rio Grande at NM-28 Bridge near San } \\
\text { Pablo, NM }\end{array}$ & $4 / 3 / 2018$ & 11:58 a.m. & 756 & $\mathrm{ADCP} / \mathrm{ADV}$ & $\mathrm{F}$ & Steady & Uneven, soft, sand \\
\hline $14 \mathrm{~A}$ & 321131106441410 & Wasteway below NM28, San Pablo & $4 / 3 / 2018$ & - & - & - & - & No flow & - \\
\hline 15 & 321014106431410 & $\begin{array}{l}\text { Santo Tomas River Drain at Levee } \\
\text { Road near San Miguel, NM }\end{array}$ & $4 / 3 / 2018$ & - & - & - & - & No flow & - \\
\hline 16 & 320943106425810 & $\begin{array}{l}\text { Rio Grande NM-192 Bridge near San } \\
\text { Miguel, NM }\end{array}$ & $4 / 3 / 2018$ & 2:42 p.m. & 586 & $\mathrm{ADCP} / \mathrm{ADV}$ & $\mathrm{P}$ & Steady & Uneven, soft, sand \\
\hline 17 & 320648106400510 & $\begin{array}{l}\text { Rio Grande at NM-189 Bridge near } \\
\text { Vado, NM }\end{array}$ & $4 / 3 / 2018$ & 4:39 p.m. & 577 & $\mathrm{ADCP}$ & $P$ & Steady & Uneven, soft, sand \\
\hline 18 & 320610106393110 & $\begin{array}{l}\text { Del Rio Drain at Levee Road near } \\
\text { Vado, NM }\end{array}$ & $4 / 3 / 2018$ & - & - & - & - & No flow & - \\
\hline
\end{tabular}




\begin{tabular}{|c|c|c|c|c|c|c|c|c|c|}
\hline $18 \mathrm{~A}$ & 320525106393410 & $\begin{array}{l}\text { Dona Ana County South Central } \\
\text { WWTP Outfall near Vado, NM }\end{array}$ & $4 / 3 / 2018$ & - & 0.63 & Reported-MDI & $\mathrm{P}$ & - & - \\
\hline 19 & 320356106394510 & $\begin{array}{l}\text { Rio Grande at NM-226 Bridge near } \\
\text { Berino, NM }\end{array}$ & $4 / 3 / 2018$ & 9:16 a.m. & 683 & ADPC & $\mathrm{F}$ & Steady & Uneven, soft, sand \\
\hline 20 & 320214106392510 & $\begin{array}{l}\text { La Mesa Drain at Levee Road near } \\
\text { Chamberino, NM }\end{array}$ & $4 / 4 / 2018$ & - & - & - & - & No flow & - \\
\hline 21 & 320212106391810 & $\begin{array}{l}\text { Rio Grande below La Mesa Drain near } \\
\text { Chamberino, NM }\end{array}$ & $4 / 4 / 2018$ & 6:25 p.m. & 676 & $\mathrm{ADCP}$ & $\mathrm{P}$ & Steady & Uneven, soft, sand \\
\hline $21 \mathrm{~A}$ & 320122106385610 & $\begin{array}{l}\text { Anthony WWTP Outfall at NM-186 } \\
\text { Bridge near Anthony, NM }\end{array}$ & $4 / 4 / 2018$ & - & - & Reported-MDI & $\mathrm{P}$ & - & - \\
\hline 22 & 315958106380710 & $\begin{array}{l}\text { Rio Grande at NM-225 Bridge near } \\
\text { Anthony, NM }\end{array}$ & $4 / 4 / 2018$ & 10:27 a.m. & 733 & $\mathrm{ADCP} / \mathrm{ADV}$ & $\mathrm{F}$ & Steady & Uneven, soft, sand \\
\hline 23 & 315957106380610 & $\begin{array}{l}\text { Pipe Inflow at NM-225 Bridge near } \\
\text { Anthony, NM }\end{array}$ & $4 / 4 / 2018$ & - & - & $\mathrm{ADV}$ & - & Steady & - \\
\hline 24 & 315807106361910 & $\begin{array}{l}\text { East Side Drain at Levee Road near } \\
\text { Anthony, TX }\end{array}$ & $4 / 4 / 2018$ & - & - & - & - & No flow & - \\
\hline 25 & 315733106361610 & $\begin{array}{l}\text { Rio Grande at Vinton Bridge near } \\
\text { Vinton, TX }\end{array}$ & $4 / 4 / 2018$ & 1:01 p.m. & 834 & $\mathrm{ADCP}$ & G & Steady & Uneven, soft, sand \\
\hline 26 & 315454106360610 & $\begin{array}{l}\text { Rio Grande at TX-259 Bridge, } \\
\text { Canutillo, TX }\end{array}$ & $4 / 4 / 2018$ & 4:20 p.m. & 693 & $\mathrm{ADCP} / \mathrm{ADV}$ & G & Steady & Uneven, soft, sand \\
\hline 27 & 315309106355510 & $\begin{array}{l}\text { Rio Grande at Borderland Bridge near } \\
\text { Borderland, TX }\end{array}$ & $4 / 4 / 2018$ & 4:55 p.m. & 762 & $\mathrm{ADCP}$ & $\mathrm{F}$ & Steady & Uneven, soft, sand \\
\hline 28 & 315046106361810 & $\begin{array}{l}\text { Rio Grande at TX-260 Bridge near } \\
\text { Santa Teresa, NM }\end{array}$ & $4 / 4 / 2018$ & 9:55 a.m. & 662 & $\mathrm{ADCP}$ & $\mathrm{F}$ & Steady & Uneven, soft, sand \\
\hline $28 \mathrm{~A}$ & 314924106355410 & $\begin{array}{l}\text { Montoya A Lateral WW } 36 \text { near } \\
\text { El Paso, TX }\end{array}$ & $4 / 4 / 2018$ & 12:37 p.m. & 5.92 & $\mathrm{ADV}$ & G & Steady & Uneven, soft, sand \\
\hline 29 & 314824106345710 & Rio Grande near Sunland Park, NM & $4 / 4 / 2018$ & 11:03 a.m. & 744 & $\mathrm{ADCP} / \mathrm{ADV}$ & $\mathrm{F}$ & Steady & Uneven, soft, sand \\
\hline 30 & 314755106332510 & $\begin{array}{l}\text { Sunland Park WWTP Outfall, Sunland } \\
\text { Park, NM }\end{array}$ & $4 / 4 / 2018$ & 12:51 p.m. & 1.71 & Reported-MDI & $\mathrm{P}$ & - & - \\
\hline 31 & 314756106331610 & $\begin{array}{l}\text { Rio Grande at Sunland Park Bridge, } \\
\text { Sunland Park, NM }\end{array}$ & $4 / 4 / 2018$ & 1:04 p.m. & 699 & $\mathrm{ADCP} / \mathrm{ADV}$ & $\mathrm{F}$ & Steady & Uneven, soft, sand \\
\hline 32 & 314810106324610 & Montoya Drain at Sunland Park, NM & $4 / 4 / 2018$ & 1:48 p.m. & 1.17 & ADV & $\mathrm{P}$ & Steady & Uneven, soft, sand \\
\hline $32 \mathrm{~A}$ & 314812106324410 & $\begin{array}{l}\text { El Paso Electric River Outfall, Sunland } \\
\text { Park, NM }\end{array}$ & $4 / 4 / 2018$ & 1:06 p.m. & 21.8 & $\mathrm{ADCP}$ & $\mathrm{P}$ & Steady & Uneven, soft, sand \\
\hline 33 & 314818106323910 & Keystone Reservoir Inlet, El Paso, TX & $4 / 4 / 2018$ & - & - & - & - & No flow & - \\
\hline $33 \mathrm{~A}$ & 314813106322810 & $\begin{array}{l}\text { Side-Channel Inlet above Courchesne } \\
\text { Bridge, El Paso, TX }\end{array}$ & $4 / 4 / 2018$ & - & - & - & - & No flow & - \\
\hline 34 & 08364000 & Rio Grande at El Paso, TX & $4 / 4 / 2018$ & 2:51 p.m. & 777 & $\mathrm{ADCP}$ & $\mathrm{F}$ & Steady & Uneven, soft, sand \\
\hline
\end{tabular}


Table 4. Summary of the cumulative gain or loss in streamflow due to seepage along subreaches within the study reach, Rio Grande seepage investigations, 2006-15 and 2018.

$\left[\mathrm{ft}^{3} / \mathrm{s}\right.$, cubic foot per second; $Q_{S}$, net seepage gain or loss. See text for equations and description of uncertainty computation; -, not measured; \pm , plus or minus]

\begin{tabular}{|c|c|c|c|c|c|c|}
\hline Year & $\begin{array}{l}\text { Length of study } \\
\text { reach (miles) }\end{array}$ & $\begin{array}{c}\text { Number of } \\
\text { sites visited }(M)\end{array}$ & $\begin{array}{l}\text { Number of sites } \\
\text { with measurable } \\
\text { flow }\left(N_{1}\right)\end{array}$ & $\begin{array}{c}\text { Percentage } \\
\text { of sites with } \\
\text { measurable flow } \\
\left(N / N_{1}\right)\end{array}$ & $\begin{array}{c}\text { Initial streamflow } \\
\text { at site } 1 \\
\left(\mathrm{ft}^{3} / \mathrm{s}\right)\end{array}$ & $\begin{array}{c}\text { Cumulative sum of } Q_{s} \\
\left(\mathrm{ft}^{3} / \mathrm{s}\right)\end{array}$ \\
\hline 2006 & 62.4 & 39 & 31 & 79.5 & 6.67 & $-36.2 \pm 2.7$ \\
\hline 2007 & 62.4 & 37 & 34 & 91.9 & 28.7 & $-36.3 \pm 6.7$ \\
\hline 2008 & 62.4 & 37 & 33 & 89.2 & 17.7 & $-41.4 \pm 3.5$ \\
\hline 2009 & 62.4 & 38 & 33 & 86.8 & 31.0 & $-47.9 \pm 8.2$ \\
\hline 2010 & 20.2 & 19 & 18 & 94.7 & - & $-10.5 \pm 3.4$ \\
\hline 2011 & 20.2 & 18 & 13 & 72.2 & - & $-8.2 \pm 3.1$ \\
\hline 2012 & 64 & 41 & 16 & 39.0 & 1.31 & $-16.2 \pm 2.1$ \\
\hline 2013 & 64 & 41 & 15 & 36.6 & 0.696 & $-19.3 \pm 2.5$ \\
\hline 2014 & 64 & 42 & 16 & 38.1 & 1.06 & $-16.0 \pm 2.9$ \\
\hline 2015 & 64 & 42 & 16 & 38.1 & 1.22 & $-17.3 \pm 2.6$ \\
\hline 2018 & 62.4 & 41 & 28 & 68.3 & 917 & $-55.7 \pm 111.3$ \\
\hline
\end{tabular}

\section{Summary}

Increasing water demand, as well as multiyear drought conditions, within the Mesilla Basin and adjacent areas has resulted in diminished surface-water supplies and increased groundwater withdrawals in the basin. In 1987, the U.S. Geological Survey (USGS) established the Mesilla Basin monitoring program to document and identify trends in groundwater conditions and relations between streams and aquifers. Seepage investigations along a 64-mile reach of the Rio Grande from below Leasburg Dam, Leasburg, New Mexico, to above American Dam, El Paso, Texas, were conducted annually by the USGS from 1988 to 1998 and from 2006 to 2015. These past studies were conducted during no-flow or low-flow periods. In 2018, a seepage investigation was conducted on April 3-4 during high-flow bankfull conditions due to upstream irrigation releases from Caballo Dam. During the investigation streamflow in the Rio Grande ranged from 577 to 1,000 cubic feet per second $\left(\mathrm{ft}^{3} / \mathrm{s}\right)$. The study reach was 62.4 miles long, from below Leasburg Dam, Leasburg, New Mexico, to above El Paso, Texas. There was no reported precipitation in the area 7 days prior to or during the study.

During the seepage investigation, there was measurable streamflow at 31 of the 41 measurement locations: 22 river sites, 8 inflow sites, and 1 outflow site. Computations presented for the investigation include net seepage gain or loss, estimation of uncertainty for each measurement, and determination of meaningful computed seepage gain or loss.
Net seepage gain or loss was computed for each subreach by subtracting the streamflow measured at the upstream location from the streamflow measured at the closest downstream location along the river, subtracting any inflow, and adding any inflow to the river within the subreach. Individual streamflow measurements were assigned a qualitative accuracy rating that represents the percentage of uncertainty in an individual measurement. Qualitative accuracy ratings were based on a subjective evaluation of the measurement made by the hydrographer on the basis of multiple factors that could affect the quality of the measurement. The uncertainty in the streamflow measurement was assigned a numerical value, derived from the qualitative accuracy rating, as follows: excellent, 2 percent; good, 5 percent; fair, 8 percent; and poor, 10 percent. The cumulative measurement uncertainty associated with the computed net seepage gain or loss for each subreach was determined.

To allow for comparison between subreaches with varying streamflows, the percentage of normalized seepage gain or loss and normalized cumulative uncertainty were computed for each subreach. A computed gain or loss for a subreach was considered meaningful if the percentage of normalized seepage difference was greater than or equal to the percentage of normalized cumulative uncertainty. Of the 21 subreaches, gaining and losing subreaches were equally distributed spatially with 10 subreaches gaining water and 11 subreaches losing water. Nine subreaches were found to have meaningful net seepage gain or loss, four gaining subreaches and five losing subreaches. The measured cumulative seepage loss of the 62.4-mile study reach in 2018 
was $-55.7 \mathrm{ft}^{3} / \mathrm{s}$. The loss was less than the cumulative error of plus or minus $111.3 \mathrm{ft}^{3} / \mathrm{s}$ computed for the study reach along with the inputs and outflows. This study, like all of the previous USGS seepage studies on this reach of the Rio Grande, reported a net seepage loss, and the magnitude of that loss was within the range of historical values. River conditions during the 2018 investigation consisted of high flows and a bankfull channel, which were unique relative to past seepage investigations that were conducted during no-flow to low-flow conditions.

\section{References Cited}

Beal, L.V., and Gold, R.L., 1989, Water resources data, New Mexico, water year 1988: U.S. Geological Survey Water Data Report NM-88-1, 504 p., accessed December 16, 2017, at https://pubs.usgs.gov/wdr/1988/nm-88-1/report. pdf.

Borland, J.P., Cruz, R.R., McCracken, R.L., Lepp, R.L., Ortiz, D., and Shaull, D.A., 1991, Water resources data, New Mexico, water year 1990: U.S. Geological Survey Water Data Report NM-90-1, 584 p., accessed December 16, 2017, at https://pubs.usgs.gov/wdr/1990/nm-90/report.pdf.

Borland, J.P., DeWees, R.L., McCracken, R.L., Lepp, R.L., Ortiz, D., and Shaull, D.A., 1990, Water resources data, New Mexico, water year 1989: U.S. Geological Survey Water Data Report NM-89-1, 440 p., accessed December 16, 2017, at https://pubs.usgs.gov/wdr/1989/nm-89/report. pdf.

Borland, J.P., DeWees, R.L., McCracken, R.L., Lepp, R.L., Ortiz, D., and Shaull, D.A., 1992, Water resources data, New Mexico, water year 1991: U.S. Geological Survey Water Data Report NM-91-1, 588 p., accessed December 16, 2017, at https://pubs.usgs.gov/wdr/1991/nm-91/report. pdf.

Borland, J.P., and Ong, K., 1995, Water resources data, New Mexico, water year 1994: U.S. Geological Survey Water Data Report NM-94-1, 606 p., accessed December 16, 2017, at https://pubs.usgs.gov/wdr/1994/nm-94-1/report. pdf.

Briody, A.C., Robertson, A.J., and Thomas, N., 2016a, Seepage investigation of the Rio Grande from below Leasburg Dam, Leasburg, New Mexico, to above American Dam, El Paso, Texas, 2014: U.S. Geological Survey Scientific Investigations Report 2016-5010, 15 p., accessed December 16, 2017, at https://pubs.er.usgs.gov/publication/ $\operatorname{sir} 20165010$.
Briody, A.C., Robertson, A.J., and Thomas, N., 2016b, Seepage investigation of the Rio Grande from below Leasburg Dam, Leasburg, New Mexico, to above American Dam, El Paso, Texas, 2015: U.S. Geological Survey Scientific Investigations Report 2016-5011, 15 p., accessed December 16, 2017, at https://pubs.er.usgs.gov/publication/ sir20165011.

Byrd, D., Allen, H.R., and Montaño, M., 2005, Water resources data, New Mexico, water year 2004: U.S. Geological Survey Water Data Report NM-04-1, 469 p., accessed December 16, 2017, at https://pubs.usgs.gov/ wdr/2004/wdr-nm-04-1/nmadr.pdf.

Crilley, D.M., Matherne, A.M., Thomas, N., and Falk, S.E., 2013, Seepage investigations of the Rio Grande from below Leasburg Dam, Leasburg, New Mexico, to above American Dam, El Paso, Texas, 2006-13: U.S. Geological Survey Open-File Report 2013-1233, 34 p., accessed December 16, 2017, at http://pubs.usgs.gov/of/2013/1233/.

Cruz, R.R., DeWees, R.K., Funderburg, D.E., Lepp, R.L., Ortiz, D., and Shaull, D.A., 1993, Water resources data, New Mexico, water year 1992: U.S. Geological Survey Water Data Report NM-92-1, 554 p., accessed December 16, 2017, at https://pubs.usgs.gov/wdr/1992/nm-92-1/report. pdf.

Cruz, R.R., DeWees, R.K., Funderburg, D.E., Lepp, R.L., Ortiz, D., and Shaull, D.A., 1994, Water resources data, New Mexico, water year 1993: U.S. Geological Survey Water Data Report NM-93-1, 620 p., accessed December 16, 2017, at https://pubs.usgs.gov/wdr/1993/nm-93-1/report. pdf.

Elephant Butte Irrigation District [EBID], 2018, EBID Water Resource Information System: Elephant Butte Irrigation District, accessed April 5, 2018, at http://onerain.ebid-nm. org/home.php.

Gunn, M.A., and Roark, M.D., 2014, Seepage investigation on the Rio Grande from below Caballo Reservoir, New Mexico, to El Paso, Texas, 2012: U.S. Geological Survey Scientific Investigations Report 2014-5197, 29 p., accessed December 16, 2017, at https://pubs.er.usgs.gov/publication/ sir20145197.

Hendricks, E.L., 1964, Compilation of records of surface waters of the United States, October 1950 to September 1960: U.S. Geological Survey Water-Supply Paper 1732, 574 p., accessed December 16, 2017, at http://pubs.usgs. gov/wsp/1732/report.pdf.

Miller, L.K., and Stiles, J.A., 2006, Water resources data, New Mexico, water year 2005: U.S. Geological Survey Water Data Report NM-05-1, 500 p., accessed December 16, 2017, at https://pubs.usgs.gov/wdr/2005/wdr-nm-05-1/pdf/ wdr-nm-05-1.pdf. 
Moyer, D.L., Anderholm, S.K., Hogan, J.F., Phillips, F.M., Hibbs, B.J., Witcher, J.C., Matherne, A.M., and Falk, S.E., 2013, Knowledge and understanding of dissolved solids in the Rio Grande-San Acacia, New Mexico, to Fort Quitman, Texas, and plan for future studies and monitoring: U.S. Geological Survey Open-File Report 2013-1190, 55 p., accessed December 16, 2017, at https://pubs.usgs.gov/ of/2013/1190/pdf/ofr2013-1190.pdf.

National Climatic Data Center, 2018, Climate Data OnlineQuality controlled local climatological data, COOP station 412797, El Paso International Airport, El Paso, TX: National Oceanic and Atmospheric Administration, accessed May 2018 at http://www.ncdc.noaa.gov/cdo-web/.

National Drought Mitigation Center, 2018, United States Drought Monitor, New Mexico tabular data archive: accessed February 14, 2018, at http://droughtmonitor.unl. edu/Data/DataTables.aspx.

Nolan, K.M., and Shields, R.R., 2000, Measurement of stream discharge by wading: U.S. Geological Survey WaterResources Investigations Report 00-4036, on CD-ROM.

Ortiz, D., and Lange, K.M., 1996, Water resources data, New Mexico, water year 1995: U.S. Geological Survey WaterData Report NM-95-1, 644 p., accessed December 16, 2017, at https://pubs.usgs.gov/wdr/1995/nm-95-1/report. pdf.

Ortiz, D., and Lange, K.M., 1997, Water resources data, New Mexico, water year 1996: U.S. Geological Survey WaterData Report NM-96-1, 470 p., accessed December 16, 2017, at https://pubs.usgs.gov/wdr/1996/nm-96-1/report. pdf.

Ortiz, D., Lange, K.M., and Beal, L., 1998, Water resources data, New Mexico, water year 1997: U.S. Geological Survey Water-Data Report NM-97-1, 6,100 p., accessed December 16, 2017, at https://pubs.usgs.gov/wdr/1997/ nm-97-1/report.pdf.

Ortiz, D., Lange, K.M., and Beal, L., 1999, Water resources data, New Mexico, water year 1997, volume 1-The Rio Grande Basin; the Mimbres River Basin; and the Tularosa Basin: U.S. Geological Survey Water-Data Report NM-981, 430 p., accessed December 16, 2017, at https://pubs.usgs. gov/wdr/1997/nm-97-1/report.pdf.

Rantz, S.E., and others, 1982, Measurement and computation of streamflow, volume 1-Measurement of stage and discharge: U.S. Geological Survey Water-Supply Paper 2175, 284 p., accessed December 16, 2017, at http://pubs. usgs.gov/wsp/wsp2175/.

Sauer, V.B., and Meyer, R.W., 1992, Determination of error in individual discharge measurements: U.S. Geological Survey Open-File Report 92-144, 21 p., accessed December 16, 2017, at http://pubs.usgs.gov/of/1992/ofr92-144/.
Simonds, F.W., and Sinclair, K.A., 2002, Surface water-ground water interactions along the Lower Dungeness River and vertical hydraulic conductivity of streambed sediments, Clallam County, Washington, September 1999-July 2001: U.S. Geological Survey Water-Resources Investigations Report 02-4161, 60 p., accessed December 16, 2017, at https://pubs.usgs.gov/wri/pdf/wri024161.pdf.

Turnipseed, D.P., and Sauer, V.B., 2010, Discharge measurements at gaging stations: U.S. Geological Survey Techniques and Methods, book 3, chap. A8, 87 p., accessed December 16, 2017, at http://pubs.usgs.gov/tm/tm3-a8/.

U.S. Geological Survey, 2013, Dictionary of water terms: U.S. Geological Survey, accessed June 7, 2018, at https:// www.usgs.gov/special-topic/water-science-school/science/ dictionary-water-terms.

U.S. Geological Survey, 2018, USGS water data for the Nation: U.S. Geological Survey National Water Information System database, accessed June 10, 2018, at https://doi. org/10.5066/F7P55KJN.

Wheeler, J.D., and Eddy-Miller, C.A., 2005, Seepage investigation on selected reaches of Fish Creek, Teton County, Wyoming, 2004: U.S. Geological Survey Scientific Investigations Report 2005-5133, 20 p., accessed December 16, 2017, at http://pubs.usgs.gov/sir/2005/5133/.

Wilberg, D.E., and Stolp, B.J., 2005, Seepage investigation and selected hydrologic data for the Escalante River drainage basin, Garfield and Kane Counties, Utah, 19092002: U.S. Geological Survey Scientific Investigations Report 04-5233, 39 p., accessed December 16, 2017, at http://pubs.usgs.gov/sir/2004/5233/PDF/SIR2004_5233.pdf.

Wilkins, D.W., 1986, Geohydrology of the southwest alluvial basins regional aquifer-systems analysis, parts of Colorado, New Mexico, and Texas: U.S. Geological Survey WaterResources Investigations Report 84-4224, 72 p., accessed December 16, 2017, at https://pubs.usgs.gov/wri/1984/4224/ report.pdf. 
For more information about this publication, contact Director, New Mexico Water Science Center

U.S. Geological Survey

6700 Edith Blvd.

Albuquerque, NM 87113

For additional information visit https://www.usgs.gov/centers/nm-water

Publishing support provided by Lafayette Publishing Service Center 


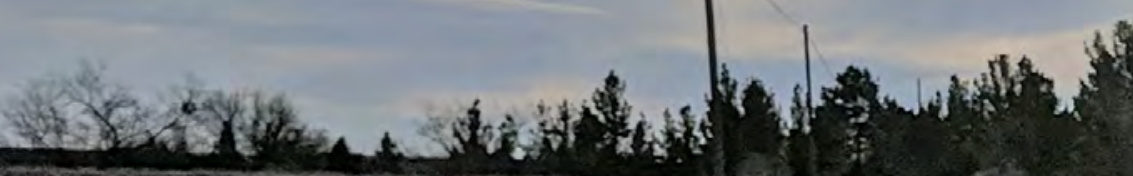

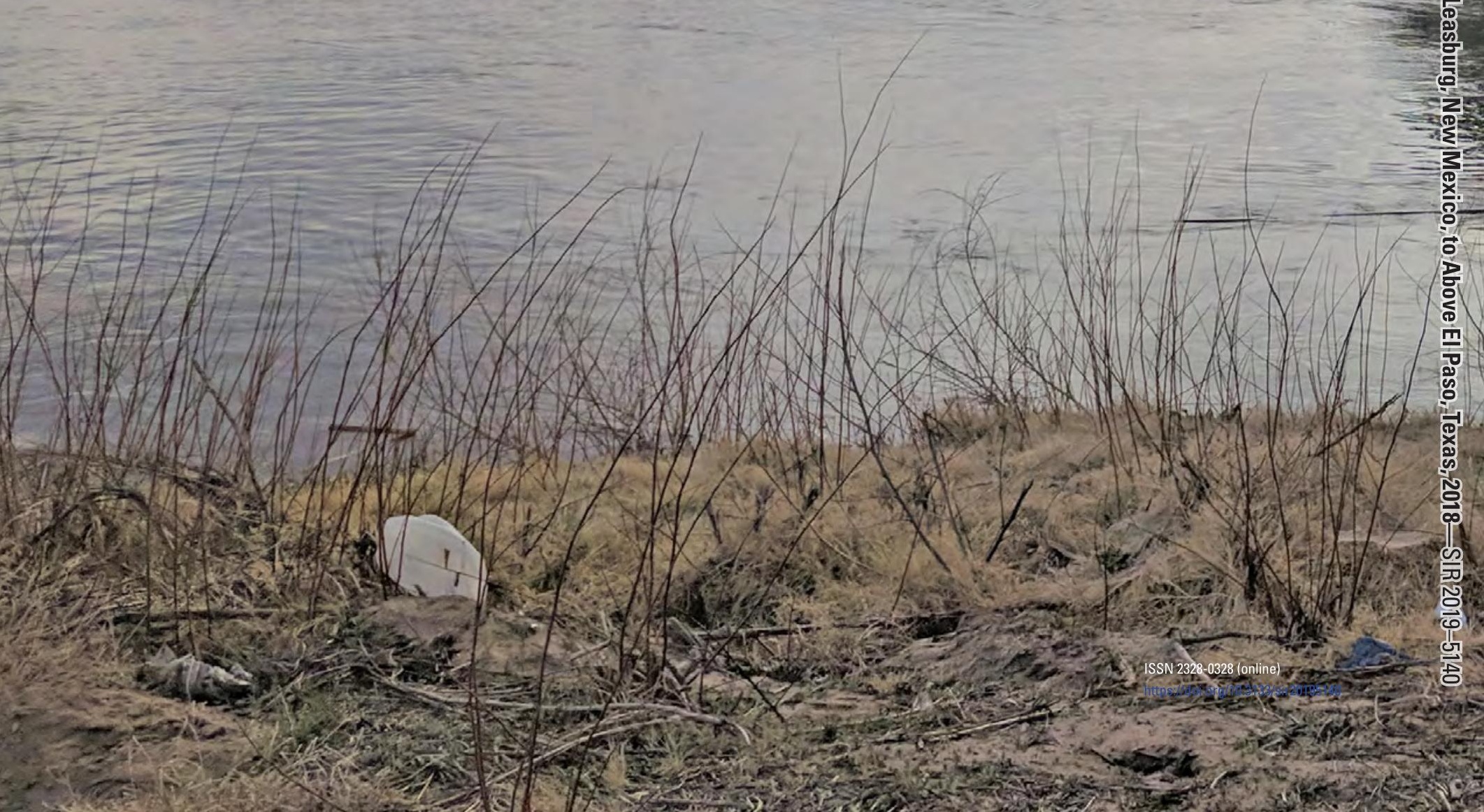

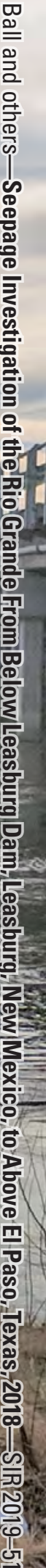

